\title{
Social barnavård i nya former. Om marknadsorientering inom barnavårdsarbetet
}

\author{
STEFAN WIKLUND
}

\begin{abstract}
Vad händer när man försöker marknadsanpassa social barnavärd? Den här artikeln diskuterar effekterna av införandet av en beställar-/utförarmodell och andra marknadsorienterade inslag $i$ arbetet med utsatta barn inom socialtjänsten.
\end{abstract}

\section{Inledning}

Hur socialtjänstens individ- och familjeomsorg - dvs. socialt arbete med socialbidrag, barn/ungdom och missbruk - organiseras är huvudsakligen en kommunal affär. Särskilt under de senaste tio till femton åren har variationerna i organiseringen mellan olika kommuner ökat. Frågan om vilka organisationsmodeller som är optimerade ur ett klientperspektiv, mest resurseffektiva, eller bäst lämpade för olika uppgifter har

Stefan Wiklund är doktorand vid institutionen för socialt arbete, Stockholms universitet. Denna artikel är ett led i ett avhandlingsarbete som rör organisatoriska villkor, strukturella sammanhang och utfall inom den sociala barnavården. därmed kommit att bli alltmer intressant. Kunskapsläget på området är dock starkt begränsat, vilket medför att bevekelsegrunder för omorganiseringar huvudsakligen utgörs av teoretiska spekulationer eller normativa ställningstaganden.

Den här artikeln handlar om organisatoriska förändringar inom en del av socialtjänstens individ- och familjeomsorg, nämligen social barnavård. Förutsättningarna för det kommunala barnavårdsarbetet har förändrats under senare tid. Inom offentlig sektor har organisationsidéer som med ett samlande begrepp brukar kallas för New Public Management (NPM) vunnit mark. NPM - eller marknadsorientering som ibland kommer att användas synonymt - är ett tämligen vitt begrepp som har en rad skilda 
empiriska referenter. I samlingsbegreppet innefattas vanligen sådana fenomen som ökad grad av privatisering, ekonomistyrning samt införande av marknadsmodeller inom offentlig sektor. Marknadsorienteringens inflytande på det svenska barnavårdsfältet har hittills främst bestått av en rörelse från kommunalt till enskilt huvudmannaskap inom institutionsvård. Stegvis har dessutom ledarskapsmodeller med rötter i näringslivet liksom starkare ekonomistyrning fått ett ökat genomslag inom socialt arbete. Man kan också notera en etablering av marknadsbaserade organisationsmodeller inom kommunerna, även om det inte tillhör vanligheterna att socialt barnavårdsarbete organiseras i så kallade beställar-/utförarmodell. Oaktat beställar-/utförarmodellens utbredning har kunskap om dess konsekvenser ett värde eftersom den faktiskt förekommer och dessutom har förekommit under en längre tid inom barnavården samt andra delar av socialtjänsten; ofta med förespeglingar om effektivitetsvinster i kommunerna samt ökad tydlighet och valfrihet för klienterna. Trots att organisationsformen förekommit under en längre tid samt att värdeomdömen om densamma är tämligen frekventa, har den empiriska granskningen varit starkt begränsad (se dock Blom 1998 för en diskussion av effekter på individ- och familjeomsorg allmänt; Johansson 2002a, Lundström 2000 om barnavården, Sallnäs 2000 om institutioner för barn och unga, Stenius 1999 om missbrukarvård).

Föreliggande artikel syftar till att undersöka vad som kan hända när idéer och politiska ambitioner om marknadslösningar möter en lokal barnavårdsorganisation. Följande frågeställningar behandlas:
- Vilka avtryck har de politiska ambitionerna fått i den praktiska verksamheten?

- Vad är personalens upplevelser av marknadsorienteringen?

- Hur kan en beställar-/utförarmodell gestalta sig i praktiken?

Stockholms stad har valts för undersökningen, eftersom staden under 1990-talet och början av 2000-talet var en viktig arena för dessa marknadstrender. Stadens tidigare politiska ledning gick i bräschen för att åstadkomma privatiseringar och konkurrensförhållanden inom individ- och familjeomsorgen. I artikeln presenteras en stadsdelsövergripande beskrivning av förekomsten av marknadsorienterade element inom stadens barnavård. Dessutom ges en förhållandevis detaljerad beskrivning från en specifik stadsdel av hur en beställar-/ utförarorganisation på barnavårdsområdet fungerar. Resultaten diskuteras utifrån begreppet NPM.

\section{New Public Management}

Kraven på förändringar av den offentliga sektorns storlek, struktur och funktion har under de senaste två decennierna haft en stor genomslagskraft i de industrialiserade länderna. I vissa stycken har det också skett reella förändringar av offentlig styrning och organisering, även om de i flera avseenden tar sig skilda uttryck mellan dessa länder (Sahlin-Andersson 2002, Chrisensen \& Lagreid 2002, Pollit \& Bouckaert 2000). Den minsta gemensamma nämnaren tycks vara att näringsliv och marknad utgör referenspunkt för förändringar. Det finns en bred 
uppsättning uttryck som hänförs till denna reformtrend. Dels rör det sig om etablerandet av olika processer inom sektorns befintliga organisationer, som ökad ekonomistyrning samt privatiseringsstimulerande åtgärder. Dels handlar det om strukturella förändringar av själva organiseringen, som införande av marknadsmodeller i olika former (Pollit \& Bouckaert 2000, Lane 2000).

NPM är det begrepp som har lanserats för att benämna och teoretiskt analysera denna spretiga trend inom offentlig förvaltning. Trendens spretighet har att göra med att begreppet knappast utgår från en solid teori. Troligtvis är det mer adekvat att tala om ett slags överförd näringslivskultur där teoretisk inspiration huvudsakligen har hämtats från olika nationalekonomiska skolor (Christensen \& Laegreid 2002). Förmodligen är det mer fruktbart att se grunderna till trendens appellationskraft som en reaktion på de senaste decenniernas ekonomiska urholkning av offentlig sektor både nationellt och internationellt, samtidigt som kritik har formulerats mot effektivitetsbrister i densamma. Ett övergripande argument i denna riktning är att den offentliga sektorns andel av samhällsekonomin bör hållas låg (se t.ex. Lane 2002).

Samtidigt pekar NPM:s förespråkare på att det övergripande målet är att effektivisera sektorn, så att åtminstone samma resultat åstadkommes till en lägre kostnad (Lane 2002). Huruvida detta sker finns ytterst litet empirisk kunskap om (Pollit \& Bouckaert 2000). Således är det i stort en öppen fråga i vilken utsträckning NPM ska ses som effektivisering av användningen av den offentliga sektorns resurser eller enbart som ett verktyg för att reducera dessa resurser. Den senare tolkningen gör det möjligt att hävda, att NPM endast utgör ett slags medel för att få kontroll över offentliga utgifter. Bergmark (1994) har talat om en ekonomisering av socialbidragshandläggningen i Sverige. Med detta menar han att kostnadsbesparingar har blivit mer centralt i takt med att kommunernas ekonomi har försvagats. På liknande sätt är det möjligt att använda sig av ekonomiseringsbegreppet för att tolka marknadsorientering som ett redskap för att åstadkomma kostnadsbesparingar i offentlig sektor utan att effektivisering - i meningen bättre resursutnyttjande-sker.

Huruvida NPM åstadkommer en effektivisering eller ekonomisering av offentlig verksamhet är svårt att mäta. Ett rimligt antagande är att marknadsorienteringens eventuella förtjänster varierar med typ av tjänsteproduktion. Dessutom är det viktigt att understryka, att omorganisationer görs i en specifik lokal kontext. Därmed finns skäl att tro, att det görs omtolkningar och anpassningar av NPM:s teoretiska idéer på det lokala planet. Johansson (2002b) har till exempel beskrivit att mottagarna av mer generella organisationsidéer troligen översätter snarare än kopierar dem. Det sker således ett slags transformation av det generella i det lokala. Fernler (2002) har i en studie av tre kommuner också visat, att implementeringen av beställar-/utförarmodeller genererar såväl generella som individuella drag (se även Blomberg 2004).

\section{Vad har skett i Sverige?}

Internationellt sett har Sverige intagit en 
mellanposition eller till och med en något återhållen position jämfört med andra industrialiserade länder avseende marknadsreformer inom offentlig sektor. Pollit och Bouckaert (2000) har i en studie av tio OECD-länder hänfört Sverige till de nationer som urskiljer sig genom en allmän uppluckring av byråkratisk stelbenthet samt en ökad fokusering på resultatutvärderingar av offentlig produktion. Däremot har Sverige inte varit särskilt långt framme i etableringen av marknadsmodeller. I ett nordiskt perspektiv intar Sverige emellertid en tätposition i införandet av så kallade kvasimarknader (Montin 1997, Bogason 1998) med konkurrensutsättning och bolagisering av offentliga verksamheter. Trydegård (2001) har också påvisat en ökning inom välfärdstjänsterna - vård, skola och omsorg - av andelen anställda i företag med privata driftformer under 1990-talet. Stockholm intar här en ledande särställning med 25 procent anställda i privata företag.

På barnavårdsfältet har Sallnäs (2000) visat att privata huvudmän för s.k. HVBhem (institutioner för barn och unga) blivit markant vanligare sedan 1980. I öppenvården finns en flora av icke-offentliga vårdgivare som säljer tjänster till kommunerna. Data från IFO-projektet (se Bergmark \& Lundström i detta nummer) visar att 58 procent av kommunerna köper öppenvård på barnavårdsområdet av privata eller ideella aktörer. Beställar-/utförarorganisering inom socialtjänstens individ- och familjeomsorg är dock inte ett särskilt utbrett fenomen. Runt fem procent av kommunerna anger att de har en sådan organisationsmodell inom individ- och familjeomsorgen.
Få undersökningar har berört beställar-/utförarmodellers effekter inom individ- och familjeomsorgen. Blom (1998) har dock studerat hur relationen mellan handläggare och klient påverkas i en kvasimarknad. Författarens huvudkonklusion är att de svagaste klienterna påverkas menligt av modellen. Stenius (1999) har undersökt kommuner som haft erfarenhet av modellen inom missbrukarvården. Hon kommer bland annat fram till att effektivitet i dessa organisationer jämställs med sänkta kostnader eftersom behandlingsresultat är svåra att mäta.

Svenska studier av marknadsorientering inom social barnavård saknas helt. Westrup (2002) har dock i ett bredare perspektiv granskat ekonomisk styrning i social verksamhet. Hon menar att man snarast bör integrera olika samarbetspartners (socialtjänst, skola och förskola) i en sådan styrning för att kunna synliggöra helhetsbilden av effekterna för individen.

Även internationella studier är svårfunna. Harris (1998) har studerat arbetsledarrollen inom individ- och familjeomsorgen överlag. Han har funnit en förskjutning från ett mer handledningsorienterat ledarskap till en ökad fokusering på ekonomisk styrning i takt med att marknadsidealet fătt fäste i socialtjänsten i Storbritannien. Kirkpatrick et al. (1999) har dock undersökt beställar-/utförarmodeller inom barnavården i Storbritannien. Författarna menar att många av de förändringar som gjorts $\mathrm{i}$ huvudsak är kosmetiska och att uppdelningen mellan beställare och utförare kan vara särskilt problematiskt på barnavårdsområdet. 


\section{Organisatoriska förutsättningarför näringslivslösningar}

Beställar-/utförarorganisering utgör ett av de mer intressanta fenomen som kan hänföras till NPM. Organisationsmodellen kan utformas på olika sätt, men det är möjligt att identifiera två huvudsakliga linjer. I den första utgörs beställarsidan av en politisk nämnd och produktionen hanteras av tjänstemannaförvaltningen. I den andra sker separationen mellan beställar- och utförarsidan på tjänstemannasidan, så att en del av förvaltningen köper tjänster av en annan (Montin 1997). I denna studie berörs endast den senare varianten. Idébasen för en sådan modell är att separera behovsbedömningar och köp från själva tjänsteproduktionen samt att förlita sig på marknadsmekanismer för att koordinera tillgången på dessa tjänster (Kirkpatrick et al. 1999). Således bör konkurrens stimuleras på så sätt att den interna tjänsteproduktionen tävlar med producenter med privat och ideellt huvudmannaskap.

Förutom att förbättra konkurrensförhållandena, kan beställar-/utförarmodellen ses som en underlättande strukturell förutsättning för att åstadkomma mer processlika marknadsorienterade inslag, dvs. ökad ekonomistyrning och stimulans till privatiseringar. Med andra ord kan man säga, att trots att beställar-/utförarmodellen endast utgör en del av samlingsbegreppet NPM, så ger modellen - åtminstone i teorin - förutsättningar att åstadkomma ytterligare inslag av marknadsorientering. Genom att modellen konstituerar två separata resultatenheter med definierade ansvarsområden, underlättas möjligheten till resultatuppföljningar. Chefsrollen kan därmed tydligare omdefinieras mot ekonomistyrning och prestationsuppföljning. Dessutom underlättas förutsättningar att knoppa av utförarenheten; dvs. att förändra ägandeformen på ett sådant sätt att de anställda tar över driften, t.ex. via anbudsförfarande.

På en teoretisk nivå finns således förutsättningar för en renodlad beställar/utförarmodell att generera ett flertal marknadsorienterade element. Däremot är det rimligt att anta, att det sker en transformation eller översättning av sådana mer generella organisationsidéer (som beställar-/utförarmodellen) på det lokala planet när en konkret omorganisation genomförs (Fernler 2002, Johansson 2002a, Johansson 2002b).

Stockholm utgör ett intressant exempel på en kommun som på en politisk nivå anammat idéer om marknadsorienterade lösningar även inom barnavården. Det har funnits tydliga politiska ambitioner att försöka privatisera verksamheter genom så kallade avknoppningar, där anställda övertar huvudmannaskapet. De politiska målen att konkurrensutsätta intern verksamhet har varit tämligen långtgående och inom individ- och familjeområdet har man till och med undersökt om man kan konkurrensutsätta själva informationsinsamlingen i utredningsprocessen (Stadsledningskontoret 2000). Men vad har skett i den praktiska verksamheten? I vilken utsträckning har de politiska ambitionerna fått fäste i barnavården? Och skiljer sig de konkreta avtrycken i den lokala verksamheten från de mer generella idéer som ligger bakom NPM? 
Med dessa utgångspunkter avses att i artikeln närmare granska vad som kan hända i en barnavårdsorganisation när det förekommer idéer och politiska ambitioner att åstadkomma marknadsorienterade lösningar i verksamheten.

\section{Metod}

Undersökningen utgörs av en studie av de marknadsorienterade inslagen inom barnavården i Stockholms stad. Stockholms stad har valts ut eftersom dess tidigare politiska ledning hade starkt uttalade ambitioner att konkurrensutsätta och stimulera privatiseringar inom individ- och familjeomsorgen. Datainsamlingen gjordes under hösten 2002 i slutet av det borgerliga majoritetsstyrets mandatperiod.

Stockholm är indelat i 18 stadsdelsförvaltningar som i flera avseenden väljer sin egen organisering. Via telefonintervjuer med företrädare för barnavården i stadsdelarna genomfördes en datainsamling rörande de marknadsorienterande inslagen i verksamheten (bortfall $=1$ stadsdel). Dessa data utgör, tillsammans med dokument om den centrala organisationen, en deskriptiv bild av omfattningen av marknadsorienteringen i staden samt ger en kortfattad översikt hur dessa har vuxit fram. På basis av dessa data inringades dessutom den stadsdelförvaltning - Östermalm - som i störst utsträckning hade organiserat sitt barnavårdsarbete i linje med de politiska ambitionerna. Det avgörande kriteriet för valet av Östermalm, var att det var den enda förvaltning som entydigt beskrev sin organisation som en beställar-/utförarmo- dell. Där gjordes sedan en mer omfattande undersökning av fallstudiekaraktär.

I den valda stadsdelen arbetar beställarenheten med utredning och uppföljning medan utförarenheten svarar för olika öppenvårdsinsatser. Det är endast beställarenheten som har en fastställd budget och behandlingsenhetens verksamhet vilar (åtminstone i teorin) på att beställarenheten köper tillräckligt många i förväg prissatta tjänster. Genom intern prissättning av behandlingsverksamheter har stadsdelen lagt tydligt fokus på att försöka efterlikna betingelser som råder på en marknad.

Fallstudier används ofta i syfte att få fram detaljrik och fördjupad information om ett fenomen. I jämförelse med en klassisk fallstudie (se t.ex. Kröger 1999, Stake 1994, Stoecker 1991, Yin 1994) är undersökningen av Östermalm något mer begränsad avseende metodarsenalen (bland annat genomfördes inte någon observationsstudie).

Proceduren kan beskrivas på följande sätt: (1) genomgång av aktuella policydokument för Stockholms stad som helhet, (2) telefonintervjuer med företrädare för barnavården vid samtliga stadsdelar, (3) urval av stadsdel med tydliga marknadsorienterade drag på basis av data från telefonintervjuerna, (4) granskning av interna dokument samt en extern rapport (Svendsen 2001) som berör denna stadsdel, (5) påplats-intervjuer i stadsdelen med chefen för utförarenheten, socialsekreterare i beställar- och utförarenheterna, samt en av de chefer som deltog i planeringen av den nya organisationen.

En svårighet vid intervjuarbetet var den 
stora personalomsättningen. Chefstjänsten vid beställarenheten var vid tillfället för undersökningen vakant. Det hade inte varit meningsfullt att intervjua den chef som snart skulle anställas. Istället intervjuades socialsekreterare vid enheten. Intervjuerna - som varade mellan fyrtio minuter och en timme-bandades och skrevs ut i sin helhet. I de halvstrukturerade intervjuerna gavs intervjupersonerna utrymme att beskriva sin egen bild av organisationen. Intervjuerna gjordes utifrån en gemensam manual som anpassades till den intervjuades position (t.ex. chef respektive socialsekreterare). Intervjuerna och dokumentstudierna följdes upp med ett antal telefonsamtal för att få svar på detaljfrågor.

Eventuella reliabilitetsproblem har försökt minimeras genom att två personer deltagit i datainsamlingsfasen och där författaren har kontrollerat sina tolkningar med den andre personen. ${ }^{1}$ För att möta eventuella validitetsproblem användes olika datainsamlingsmetoder. Dessutom gjordes återkopplingar till intervjupersoner för att validera svar och tolkningar av svar. Undersökningens generaliseringsanspråk ligger i linje med vad som är rimligt i undersökningar av fallstudiekaraktär. I fallstudier generaliseras empiriska data till de teoretiska utgångspunkterna, så kallad analytisk generalisering. Sådana analytiska genera-

1 Ett stort tack till professor Tommy Lundström som givit många goda råd under arbetets gång. Artikelförfattaren har, ett par år före studiens genomförande, arbetat vid stadsdelen i fråga. Av det skälet har Lundström dessutom bidragit till att ta huvudansvaret för att leda intervjuerna. liseringar måste i denna studie dock göras med reservation för den tolknings- och transformationsprocess av NPM som kan göras i den lokala kontexten. Man kan helt enkelt förutsätta att beställar-/utförarmodeller skiljer sig åt mellan olika kommuner. Således krävs ytterligare studier på området för mer långtgående anspråk på generalisering.

\section{Barnavårdsarbete med marknadsförtecken}

Innan undersökningen av den enskilda stadsdelen presenteras, redovisas data om barnavården i Stockholm på två nivåer. Den första nivån beskriver Stockholm stads centraliserade organisation och ger en kortfattad översikt av marknadsorienteringens framväxt på en politisk nivå. Den andra nivån är stadsdelsövergripande och beskriver omfattningen av verksamhetsinslag som kan kategoriseras som marknadsorienterande.

\section{Central nivå}

År 1996 indelades Stockholms Stad i olika stadsdelsnämnder med tillhörande förvaltningar. De politiska ambitionerna med reformen var att de lokala förhållandena skulle beaktas i större utsträckning samt att förstärka den lokala närdemokratin. Antalet stadsdelsförvaltningar har varierat, men år 2002 var de arton.

Trots decentraliseringen finns en relativt omfattande central styrning och tjänsteproduktion. Förutom en central politisk 
ledning med tillhörande förvaltning finns även ett stort antal centraliserade förvaltningar som var och en leds av en politiskt tillsatt nämnd. Socialtjänstförvaltningen ansvarar för tjänster inom individ- och familjeomsorgen. Den driver bland annat Stockholm HVB med 14 institutioner på barnavårdsområdet samt missbruksmottagningen Maria Ungdom. Vidare ansvarar socialtjänstförvaltningen för vissa centrala projekt, konsultativa tjänster och uppsökarverksamhet på barnavårdsområdet (Stockholm Stad 2002).

De politiska ambitionerna att utveckla konkurrensutsättningen även inom individ- och familjeomsorgen initierades under år 2000. ${ }^{2}$ Kommunstyrelsen tillsatte då en grupp för att kartlägga möjligheterna till konkurrensutsättning av individ- och familjeomsorgen. Arbetsgruppens utredning, "Socialtjänst på entreprenad", var en omfattande genomgång av myndighetsbegreppet. I utredningen fann man att det fanns goda förutsättningar för privatiseringar (Stadsledningskontoret 2000).

Det är dock i endast en av de centraliserade verksamheterna som personal tagit över huvudmannaskapet. En jourhemsverksamhet som tidigare låg under socialtjänstförvaltningen blev år 2001 en självständig ekonomisk förening.

2 Upphandling av externa behandlingsverksamheter (som viss HVB-vård) inom individ- och familjeomsorgen har skett i konkurrens under flera år. Skillnaden här är alltså ambitionen att även intern verksamhet ska ingå i konkurrensförhållande med externa producenter.

\section{Stadsdelarna}

Förekomsten av avknoppningar på stadsdelarna är - liksom på central nivå - anmärkningsvärt liten. I telefonintervjuerna framkommer att ingen stadsdel har verksamheter som privatiserats under de tre senaste åren räknat från intervjutillfället.

En alternativ indikator på marknadsorientering utgörs av förekomsten av externa köp av behandlingstjänster från alternativa vårdgivare. Sådana typer av "marknadsrelationer" ger en bild av den roll privata aktörer spelar i förhållande till de olika stadsdelarna samt indikerar storleken på den "marknadsandel" som dessa aktörer har. Tabell 1 beskriver förekomsten av externa köp av öppenvårdsresurser från alternativa (drivna av privat eller ideell huvudman) vårdgivare bland de stadsdelar som deltog i studien. Resultaten baseras på telefonintervjustudien där respondenter med god kännedom om verksamheten har fått skatta andelen inköp av olika insatser.

Förekomsten av inköp från privata vårdgivare är inte överväldigande. Nära tre fjärdedelar av stadsdelsförvaltningarna köper öppenvårdsresurser i lägre utsträckning än 10 procent för varje vårdkategori. Vårdformen "kontaktperson" har en något högre andel. Det är framför allt aktiebolaget Barn- och ungdomsgruppen samt den ideella organisationen Fryshuset som anlitas för inköp av kvalificerade kontaktpersoner. Även i kategorin "övrig familjebehandling" tycks Barn- och ungdomsgruppen verka som en stark entreprenör. De stadsdelar som i hög grad (över 50 procent) köper in hemma-hos-verksamhet och övrig famil- 
jebehandling gör huvudsakligen så för att verksamheterna saknas i den egna organisationen.

En annan typ av tjänsteinköp är inhyrning av personal från bemanningsföretag. Detta hade under det senaste året, räknat från intervjutillfället, förekommit i sju stadsdelar. Endast vid tre stadsdelar hade det skett $i$ en omfattning motsvarade mer än en halvårstjänst.

En tredje indikator är förekomsten av beställar-/utförarmodeller. Bland stadsdelarna var det endast en som entydigt beskrev sin organisation som en beställar/utförarmodell. Däremot angav sju stadsdelar att de delvis organiserade sitt arbete efter en sådan modell. Argumenten för att de inte fullt ut ansåg sig ha modellen varierade, men vanliga svar var att myndighetsdelen svarade för viss behandling eller att de två enheterna hade gemensam chef. Den stadsdel som betraktade sig som organiserad som beställare/utförare var den enda som prissatte interna behandlingsuppdrag.

Telefonintervjuerna ger knappast en bild av särskilt omfattande inslag av marknadsorientering. Detta kan upplevas som en aning förvånande, speciellt med tanke på att t.ex. anställningsgraden inom företag med alternativ driftsform är påfallande hög i Stockholm som helhet (Trydegård 2001). Detta kan delvis förklaras av att politiska ambitioner att marknadsorientera individoch familjeomsorgen kommit senare i jämförelse med andra verksamheter. Ändå förefaller avtrycken i den praktiska verksamheten begränsade, givet den tydliga politiska kurssättningen. Möjligen förhåller det sig så att marknadsorienteringen har svårare att finna vägar inom barnavården. Kanske finns det större motstånd bland personalen eller så finns andra organisatoriska hinder som försvårar den av politikerna önskade utvecklingen. Under nästföljande rubrik presenteras data från den stadsdel som trots allt tagit till sig de politiska ambitionerna i störst utsträckning.

\section{Barnavård i beställar/ utförarrock}

Beställar-/utförarmodellen på Östermalm är utformad på tjänstemannanivå, dvs. det saknas politiska beställarnämnder. Det finns en beställarenhet och utförarenhet vardera på vuxensidan (med missbrukarvård, kommunal psykiatri samt arbete

\section{Tabell I.}

Andel externa inköp av behandlingsinsatser från alternativa vårdgivare bland Stockholms stads stadsdelar ( $n=17)$.

\begin{tabular}{lccccc}
\hline & $\begin{array}{c}\text { Kontakt- } \\
\text { personer }\end{array}$ & $\begin{array}{c}\text { Kontakt- } \\
\text { familjer }\end{array}$ & Hemma hos & $\begin{array}{c}\text { Övrig famil- } \\
\text { jebehandling }\end{array}$ & Utredningar \\
\hline$<\mathbf{1 0} \%$ & 12 & 17 & 14 & 13 & 17 \\
\hline $\mathbf{0 - 5 0} \%$ & 2 & 0 & 0 & 1 & 0 \\
$\mathbf{2 5 0} \%$ & 3 & 0 & 3 & 3 & 0 \\
\hline
\end{tabular}


med funktionshinder) och barnsidan (med barn- och ungdomsvård och arbetet med funktionshinder). Vardera beställarenhet har eget budgetansvar och formellt sett är utförarenheterna intäktsfinansierade (de ska således bekosta sin verksamhet genom intäkter från uppdragsgivare). Handläggningen av socialbidrag ingår inte $\mathrm{i}$ dessa enheter.

Modellen infördes på stadsdelen år 2000. I ett tjänsteutlåtande (Östermalms stadsdelsförvaltning 2000) anges i huvudsak två skäl för omorganisationen. För det första önskades en ökad integrering mellan individ- och familjevården och de kommunala tjänsterna för psykiatri och funktionshinder. Det andra motivet hade sin grund i det politiska direktivet att de flesta verksamheter skulle upphandlas i konkurrens. I tjänsteutlåtandet menar man att den nya organisationen skulle kunna öka integreringen mellan verksamhetsområden samt tillgodose konkurrensdirektivet på följande sätt: „Syftet är /.../ nå samverkan över kompetensområdena samt att skapa en flexibel organisationsmodell vilken underlättar för konkurrensutsättning i de fall nämnden fattar beslut om sådan" (a.a.). När datainsamlingen genomfördes i slutet hade det dock inte skett någon konkurrensutsättning inom barnavården via internt anbud vid upphandling. Däremot hade individ- och familjeomsorgen under 2002 infört ett prissättningssystem av tjänster så att utförarenheterna skulle bära sina egna kostnader.

På beställarenheten för barn och ungdom finns sju årstidsarbetare medan utförarenheten omfattar åtta årstidstjänster med traditionella individ- och familjeomsorgssysslor. Därutöver finns handläg- gare av LSS-ärenden, personal inom ungdomsmottagning samt kontrakterade kontaktpersoner. Utförarenheten, som kallar sig Östermalms familjeteam, innefattar ungdomsmottagning, familjevård, förmedlare av kontaktpersoner, familjebehandlare och familjepedagog, socialsekreterare med familjebehandlingsuppdrag samt en person som arbetar med funktionshindrade barn. Beställarenheten svarar för utredningar samt beställning och uppföljning av insatser.

Beräknade kostnader för köp av externa öppenvårdsresurser från alternativa vårdgivare uppgick till cirka 870000 kronor under 2002 för barnavården (Östermalms stadsdelsförvaltning 2002). Detta kan i runda tal översättas till kostnaderna för drygt två helårstjänster. Andelen externa inköp av öppenvård från alternativa vårdgivare understiger 10 procent i samtliga kategorier från tabell 1 . Förvaltningen hyrde in personal från bemanningsföretag $\mathrm{i}$ en omfattning mellan 2-6 heltidsmånader.

\section{Bilderfrain socialsekreterare och enhetschefer}

I det som följer presenteras data från intervjuer med socialsekreterare och enhetschefer som arbetar med barnavård på Östermalm. Tematiseringen av dessa data har skett i samspel mellan de teoretiska utgångspunkterna och vad som framkommit i intervjuerna. Det första temat handlar om ett kostnadsmedvetande i stadsdelen som har sina rötter flera år innan organiseringen i beställar-/utförarmodell (rubriken pengar och kostnader). Under detta tema 
beskrivs också hur ledarskapet har förändrats parallellt med det ökade kostnadsmedvetandet. Det andra temat rör ett motstånd som främst socialsekreterarna, men även arbetsledarna, gav uttryck för gentemot organisationsmodellen i sig samt mot marknadsorienterade processer inom modellen (rubriken motstånd och främlingskap). Det sista temat handlar om svårigheter att omsätta de marknadsorienterade processerna i praktiken (rubriken marknadsmekanismer itillämpning).

\section{Pengar och kostnader}

Intervjupersonerna gav en bild av hur ett ekonomiskt tänkande alltmer präglat arbetsvillkoren sedan slutet av 1990-talet, alltså flera år före omorganisationen. En socialsekreterare på utförarenheten beskrev ekonomins betydelse på följande sätt:

Det märks ju mycket mer i dag, pengar, pengar, pengar. Jag tror att det har smugit sig in kanske de senaste 5-6 åren, mer och mer. Pengar, pengar, pengar.

Ovanstående citat avspeglar ett slags frustration som ett flertal intervjupersoner gav uttryck för. Denna frustration var tydligast i det att ekonomiska hänsynstaganden hade kommit att bli centrala vid planering av behandlingsinsatser. Man fick dock inte intrycket att de ekonomiska betingelserna var extremt svåra på stadsdelen. Frustrationen tycktes snarare bottna i själva fokuseringen på kostnaderna; att budgeten tenderade att inta en överordnad roll i förhållande till klientarbetet.
Arbetsuppgifterna för chefspositionen omedelbart ovanför socialsekreterarna hade sedan slutet av 1990-talet, enligt flera av intervjupersonerna, förskjutits mot olika administrativa sysslor som budgetdiskussioner, verksamhetsplanering och uppföljningsarbete. Förändringen av arbetsledarrollen tycktes ha infallit parallellt med det ökade kostnadsmedvetandet. En person utan chefsbefattning beskrev på följande sätt sin uppfattning om chefsrollens förändring jämfört med för sexton år sedan då hon började i yrket:

När jag tänker hur min chef var när jag började, så var han mycket mer tillgänglig. Han hade ett större socialt engagemang /.../ och tog pengarna slut så kunde man oftast få mer. Idag kan jag känna att det är tvärtom, att man tittar först på om man har pengar, sedan fattar man beslut. Där är det lite annorlunda.

Den förändrade ledarskapsrollen fick effekter för det praktiska klientarbetet. En socialsekreterare berättade att arbetsledaren främst konsulterades vid formalitetsfrågor $i$ handläggningen. Om man ville diskutera mer substantiella frågor i klientarbetet var det vanligare att man vände sig till kollegor.

Ekonomins betydelse och arbetsledarnas ökade fokusering på kontroll över densamma initierades således på stadsdelen under senare delen av 1990-talet. Ett flertal intervjupersoner beskrev att dessa tendenser förstärktes i och med införandet av beställar-/utförarmodellen genom att socialsekreterarna på beställarenheten så gott som dagligen specificerar kostnader i insatsbeslut och att utförarenheten sedan 
debiterar denna kostnad. På arbetsledarnivå har internprissättningen tagit mycket tid. En person som sitter i ledningsgruppen pekade på den ökade administrativa bördan, men såg även vissa förtjänster med det nya systemet:

Ja, jag tycker trots all att vi inte har lyckats kunna följa upp det på det där riktigt bra sättet. Från beställarsidan är det $i$ alla fall väldigt tydligt vad en stödkontakt kostar per timme/.... Nu kostar den 917 kr i timmen. Och, jamen, då kan ju jag beställa en psykologkontakt på stan för $500 \mathrm{kr}$ i timmen. Så egentligen ska jag ha någonting bra för de här 917, alltså kopplat till kvalité./../ Det tycker jag vi har uppnått, alltså ekonomisk medvetenhet ner på timnivå, som inte är så dumt, faktiskt.

Citatet ger delvis en illustration av hur kostnadsmedvetandet kan relateras till ett effektivt resursutnyttjande. Med hjälp av prissättning av behandlingsarbetet är det möjligt att prioritera i vilken utsträckning man ska köpa insatsen eller välja andra alternativ $i$ en avvägning mellan pris per timme och kvalitet.

Sammantaget kan man dra följande slutsatser om det ökade kostnadsmedvetandet. För det första tycks det ha dykt upp flera år före beställar-/utförarorganisationen. För det andra verkar det förändra förutsättningarna för chefsrollen. För det tredje är det svårt att avgöra huruvida kostnadsmedvetandet är en effektivisering av arbetet eller om det snarare handlar om mer allmänna besparingar. En effektivisering förutsätter att det är möjligt att värdera kvaliteten eller effekterna av olika behandlings- insatser. Man kan här allmänt konstatera att det är svårt att värdera effekterna av olika behandlingsinsatser inom socialt arbete. Frånvaron av validerade utvärderingar inom området är påfallande, vilket naturligtvis försvårar avvägningar mellan pris och kvalitet för socialsekreterarna.

\section{Motstånd ochfrämlingskap}

Ett annat tydligt tema som framkom under intervjuerna var skepsis och motstånd mot det nya sättet att organisera arbetet. Någon var till och med övertygad om att organisationsformen snart skulle dö ut. Det framgick också att det fanns ett starkt motstånd bland flera socialsekreterare gentemot organisationsvarianten redan innan den sjösattes. Detta motstånd beskrivs också tydligt $i$ en rapport om omorganisationen som skrevs endast en kort tid efter dess genomförande (Svendsen 2001). En sådan inställning påverkar naturligtvis organisationens förutsättningar att fungera på ett optimalt sätt. Så här beskriver chefen för utförarenheten personalens reaktioner vid omorganisationen:

Det var ju mycket protester från beställarenheten, man säger att barnavairdsutredningar inte är någon beställning. De är ju ett behandlingsarbete $i$ sig. Den personalen har ju inte varit speciell entusiastisk över den här förändringen./.../ Det fanns en oro $i$ utförarenheten om att man skulle bli av med sina jobb, att man skulle konkurrensutsättas. Det var ju också väldigt mycket i tiden då, det här med konkurrensutsättning. Så här gör man för att bli av med oss. 
De socialsekreterare som intervjuades gav uttryck för ett tämligen unisont främlingskap inför den förändrade synen på arbetet som följde organisationsmodellen. På flera sätt framkom uppfattningen att socialt arbete och marknadsorientering är svårförenliga. Det tycks som att de flesta ansåg att det var mycket svårt att sätta ekonomiska värden på det arbete som utförs och ännu svårare att göra avkall på behandlingsalternativ på grundval av ekonomiska argument. Organiseringen med beställare och utförare medför också att tidigare kollegor ingår i en ekonomisk relation med varandra. Detta var svårhanterbart för flera av intervjupersonerna. Någon marginaliserade detta och såg det som ett nödvändigt administrativt förfarande som egentligen inte hade några praktiska konsekvenser. „Vi pratar inte så mycket om kostnader, vi skriver upp dem på insatsbesluten", sade en beställare. En annan utredare såg den ekonomiska relationen som en försvårande omständighet för det kollegiala arbetet:

Jag tycker att en förutsättning, om man ska kunna beställa tjänster av dom, är att man har en dialog om vad dom kan göra och vad dom inte kan göra samt vilket utrymme dom har. Samtidigt bör dom fä höra vad det är vi vill ha. Då tycker jag, då bör man ha en ganska tät kontakt. Då blir det mer som om man är kollegor. Nu blir dom alltså beroende av oss och våra beställningar för att dom ska kunna överleva överhuvudtaget. Redan där tycker jag det blir en onaturlig situation.

I intervjumaterialet finns det, frapperande nog, inte ett uttalande som går i riktning mot att den nya organiseringen på något sätt underlättar eller utvecklar det dagliga byråarbetet. På utförarsidan fälldes dock kommentarer om trivsel med den nya organiseringen. Trivseln härrörde från det faktum att man slapp arbeta med tvångsåtgärder och lågmotiverade klienter. Flera intervjupersoner hade dock invändningar mot den ökade pappersexercis som följde de interna beställningarna. Det interna prissättningssystemet förföll särskilt besynnerligt bland de intervjuade på utförarsidan. Så här kommenterade en socialsekreterare den interna prislistan:

Jag har inte tittat så mycket på den, om jag skall vara riktigt ärlig. Vi har gått igenom den på något sektionsmöte och så. Det känns bara främmande, hela grejen, tycker jag. För mig känns det främmande. Men det kanske beror påatt vi är ovana.

En annan, elakare, beskrivning av köp/säljsystemet gavs av en socialsekreterare på beställarsidan:

Jag känner mer att det är lite att leka affär på något sätt. Alltså att man leker lite. Man försöker anpassa det här för att få det till något slags näringsliv, fast det kanske inte funkar riktigt i den här verksamheten.

Sammantaget kan man säga att separationen mellan beställningar och utförande samt den interna prissättningen snarast betraktades som hinder i arbetet. Man kan tolka detta på tre sätt. För det första kan socialsekreterarnas motstånd hämma tänkbara positiva effekter. För det andra kan man tolka det som att organisationsvarianten 
faktiskt är svårförenlig med det praktiska sociala arbetet. För det tredje kan man säga att internprissättningen förvisso har utvecklingspotential, men att man på stadsdelen inte har satsat tillräckligt för att få det att fungera. De två första tolkningsalternativen utesluter naturligtvis inte varandra.

\section{Marknadsmekanismeri tillämpning}

Det mest påfallande intrycket av intervjuerna var den osäkerhet som präglade tilllämpningen av olika marknadsorienterade processer i praktiken. Faktorer som prissättning, beställningar och en allmänt ekonomiserad syn på verksamheten utgör således främmande ting som man har svårt att förhålla sig till. Därutöver finns även en osäkerhet hur dessa medel ska användas. Denna omständighet kan endast till del förklaras av ett ointresse bland socialsekreterare. Snarast tycks det handla om en osäkerhet eller brist på implementeringsstrategi som även finns rotad på ledningsnivå. Med andra ord har man svårt att få till stånd sådana fenomen som avknoppning, konkurrensutsättning och intäktsfinansiering av utförarenheten samt fungerande målstyrning inom beställarenheten. Kirkpatrick et al. (1999) har visat att effekterna av beställar-/utförarmodeller i Storbritannien inom barnavården huvudsakligen är kosmetiska. I föreliggande studie är visserligen förändringarna reella i den mening att de får tämligen omfattande konsekvenser för det praktiska arbetet. Däremot verkar det vara svårt att få till stånd marknadsorienterade processer, som privatiseringar.
Ett tydligt exempel är familjevårdarnas försök att ta över sin verksamhet i egen regi. Familjevårdarna ansvarar för rekrytering och uppföljning av familjehemsplaceringar och ingår i utförarenheten. Trots att den centrala ledningen hade uppmuntrat privatiseringsambitioner och till och med anordnat kurser som avhandlade ämnet, mötte familjevårdarna hinder när de framförde sina ambitioner att driva verksamheten. Det framkom inte riktigt vad som låg bakom att privatiseringsambitionerna stoppades, men så här berättar chefen för utförarenheten:

Dom fick väldigt mycket peppning uppifrån och dom var till diverse konsulter. Dom tyckte det var kul, dom ville. Så dom drev det där lite grann. Men sedan blev det allt trögare, så att dom var uppe hos direktören och programchefen. Ingen ville ta $i$ det där, för att det blivit dyrare och det fanns inga pengar.

I utförarenheten som helhet hade det inte funnits några fler uttalade avknoppningsinitiativ. Det hade inte heller funnits något större organisatoriskt tryck att upphandla verksamheten. Istället för att konkurrensutsätta utförardelen via ett anbudsförfarande valde ledningen att intäktsfinansiera verksamheten. Detta kan beskrivas som en alternativ strategi i förhållande till de politiska målen. Den person i ledningsgruppen som intervjuades gav följande förklaring till varför man inte hade valt ett anbudsförfarande:

Ja, det hade ju varit mera rejält, och det var nog ren försiktighet och lite mer omtanke om personalen. Alltså att göra den här omor- 
ganisationen innebär ju ändå att man har kvar sitt jobb och sin anställning. Arbetsuppgifterna blir lite annorlunda definierade, men $i$ huvudsak så jobbar man ändå med det som man är van att jobba med.

Genom intäktsfinansieringen förändrades enhetens ekonomiska villkor på ett sådant sätt, att den via försäljningen av sin tjänsteproduktion skulle bära sina egna kostnader. Istället för att få en ekonomisk resurstilldelning var tanken att intäkterna från verksamheten skulle finansiera enheten. Teoretiskt skulle detta kunna fungera på ett liknande sätt som vid en upphandling. Om behandlingsenheten måste konkurrera med alternativa vårdgivare via pris och behandlingskvalitet verkar den under motsvarande marknadsbetingelser som vid en upphandling. Problemet här är dels att stadsdelen hade infört ett direktiv för beställarenheten att den interna enheten skulle nyttjas i första hand, dels att man inte hade varit konsekvent med kravet på intäktsfinansiering. Därmed är det svårt att argumentera för att utförarenheten verkar i en reell konkurrenssituation. På följande sätt karaktäriserar personen i ledningsgruppen internprissättningssystemet.

Vi har ju skämtsamt kallat det lite för att "spela monopolu. Eftersom det inte har rört sig om pengar som har gått ut, utan det har ju varit liksom bara siffror på papper så här. De har ju ändå på utförandesidan fätt sin lön och fätt sin lokal betald och fätt sin utbildning och all det där, oaktat att dom fick intäkter från beställningar.

Man kan spekulera i orsakerna till svårig- heterna att skapa en intäktsfinansierad enhet. Ovanstående citat pekar på avsaknad av incitament för att bära kostnaderna, dvs. det är »business as usual» oavsett om intäkter strömmar in eller inte. Man kan här peka på ett organisatoriskt bekymmer. Så länge enheten inte är upphandlad, kan det knappast ställas några långtgående krav på att den ska vara självbärande. Om stadsdelen bestämmer sig för att lägga ned enheten för att den inte bär sina kostnader, återstår för stadsdelen att köpa in motsvarande behandlingsinsatser. På åtminstone kort sikt blir detta förmodligen dyrare och organisationens flexibilitet minskar.

Utöver svårigheten att skapa en självbärande enhet vållade även internprissättningen administrativa bekymmer inom organisationen. Så här beskrev samma person detta:

Vi har ju kämpat på med den här internprissättningen och kan konstatera att vi inte lyckats få det att fungera som instrument. Det kräver väldigt mycket tid och resurser./.../ Man tänkte att det där sköter man precis som man sköter alla andra fakturor. Det blir några till. Men det har inte riktigt varit så enkelt, utan det blev mycket mera jobb.

Arbetsledaren på utförarenheten bekräftar ovanstående bild av problemen med internprissättningen:

Alltså, budgeten har blivit väldigt svåröverskådlig med den här internprissättningen. Det är fullständigt àt helsike ur arbetssynpunkt, på något sätt, att hålla på skicka räkningar fram och tillbaka. När det gäller 
barnsidan har det varit jag som varit engagerad $i$ eftersom de har växlat cheferna. Jag har ägnat väldigt mycket tid àt det. Till vilken nytta, undrar jagju.

Under intervjuerna framkom också att det ibland var si och så med hur beställningar preciserades och följdes upp från utförarsidan. När olika intervjupersoner ombads att beskriva hur en beställning kunde se ut, var det typiska svaret att man gav utförarenheten i uppdrag att under ett visst antal timmar utgöra samtalsstöd för klienten i avsikt att diskutera familjerelationer, stöd i föräldrarollen och dylikt. Omfattning och kostnad förekommer alltid på beställningarna, men utifrån intervjupersonernas beskrivningar var målen vanligen allmänt hållna. Det var sällan man kunde formulera mer precisa beställningar, t.ex. att en förälder skulle sluta dricka eller att en ungdom skulle sluta skolka. En märklig egenhet var att beställarsidan hade lagt ut beställningar på utredningar till utförarsidan. Detta hade visserligen skett när beställarsidan hade underbemanning. En välvillig tolkare kan beskriva detta som ett tecken på flexibilitet inom organisationen. En mer kritisk tolkning är dock att förfarandet vittnar om en tämligen absurd situation där en enhet beställer utförandet av det arbete man är satt att göra.

Sammantaget gav intervjuerna bilden av osäkerhet hur man skulle göra bruk av den nya organisationsformen. För det första hade det inte skett någon upphandling av utförarsidan. För det andra framställdes den alternativa strategin med intäktsfinansieringen som en stor administrativ börda. Analytiskt är det dessutom svårt att se vilket syfte den tjänar eftersom utförarna anlitas i första hand samtidigt som kravet på enheten att vara ekonomiskt självbärande inte efterföljs. Därmed är det svårt att tala om någon egentlig konkurrensutsättning. För det tredje hade det enda avknoppningsinitiativet bland personalen stoppats. För det fjärde föreföll beställningarna vara tämligen opreciserade. De hade dessutom ibland tagit en besynnerlig skepnad i form av beställningar av utredningar (där utredningar organisatoriskt definieras som beställningar).

\section{Avslutning}

I denna artikel har förekomsten av marknadsorienterade drag inom Stockholms stads sociala barnavård analyserats. Stockholm har haft en stark politisk ambition att åstadkomma konkurrensutsättning för individ- och familjeomsorgen. Data från telefonintervjuer med representanter för barnavården i stadsdelarna visade dock att de politiska ambitionerna knappast haft något större genomslag. Beställar/utförarmodeller är ovanliga och det har inte skett någon privatisering att tala om av tjänsteproduktionen, varken i de centrala verksamheterna eller i verksamheterna på de olika stadsdelarna. Det finns således fog för att tala om ett stort avstånd mellan politiska ambitioner och konkreta utfall avseende marknadsorienteringen inom Stockholms barnavård.

En stadsdel tillämpade dock en beställar-/utförarmodell bland annat som en konsekvens av de politiska ambitionerna. I undersökningen framkom att det fanns en 
utbredd skepsis bland personalen gentemot marknadsorienterade inslag i arbetet. I intervjuerna är ett genomgående intryck att personerna på olika sätt distanserar sig till den organisationsmodell de är satta att arbeta med. Ingen uttalar sig (annat än i detaljer) i positiva ordalag. Istället återfinner man ofta ett slags ironisk distansering. De intervjuade tar inte till sig ett "marknadsspråk» utan skämtar i stället om försöken att "leka affär» och "spela monopol», och markerar också på andra sätt hur svårt det är att åstadkomma de utifrån önskade förändringarna. Man kan tolka detta som uttryck för ett slags motstånd. Personalen önskar inte dessa förändringar och markerar sitt motstånd på detta sätt. En alternativ tolkning är svårigheterna att tillämpa marknadsorientering i en verksamhet som den undersökta, och att den ironiska distanseringen skall förstås som ett uttryck för detta.

Studien av stadsdelen visade på en påfallande osäkerhet i implementeringen av de marknadsorienterade processerna. För det första hade det inte skett någon konkurrensutsättning av utförarsidan. För det andra drevs inte kravet på intäktsfinansiering så långt att åtminstone en approximation av en reell marknadssituation inträdde. För det tredje understöddes inte de avknoppningsinitiativ som togs av personalen. En tolkning är att se svårigheterna som ett utslag av omständigheter som är specifika för den undersökta stadsdelen. En sådan tolkning kan göras utifrån den transformationsprocess som kan tänkas ske när generella organisationsidéer möter lokala kontexter. På stadsdelen har visserligen generella idéer utifrån NPM materialiserats i form av en beställar-/utförmodell. Däremot uppstår hinder när centrala processer inom modellen ska ta form. Personalens motstånd kan möjligen ha varit en lokal omständighet som verkat hindrande för dessa processer. I intervjuerna framkom också att vissa hänsynstaganden gjordes gentemot personalen när man inte lät utförarenheten delta i ett anbudsförfarande. Argument som talar mot denna tolkning är dock att personalens motstånd var grundat tidigt och hindrade då inte själva omorganisationen. Dessutom fanns privatiseringsinitiativ som inte fick stöd.

Det är möjligt att göra en alternativ tolkning av stadsdelens svårigheter att implementera de marknadsorienterade processerna. Kanske bottnar svårigheterna i mer generella problem att införa marknadsorienterade element i en människobehandlande verksamhet som barnavården. En studie från Storbritannien uppvisar liknande svårigheter att få beställar-/utförarmodeller att fungera "fullt ut». Bland annat visar studien att rollerna som beställare och utförare i praktiken inte upprätthålls (Kirkpatrick et al. 1999).

Även om den senare tolkningen behöver ytterligare empirisk verifiering, kan man på ett teoretiskt plan resonera om dess giltighet. Den bärande tanken inom NPM är att effektivisera tjänsteproduktionen inom offentlig sektor; det vill säga åstadkomma mer "output» i förhållande till nedlagda produktionsresurser. Problemet är dock att det är svårt att definiera »output» i människobehandlande organisationer. Förekomsten av generaliserbara effektstudier inom barnavårdsforskning är starkt begränsad. Om det är svårt att värdera effekten av 
olika behandlingsalternativ, torde det också vara svårt att åstadkomma effektivitetsförbättringar, eftersom det är svårt att bedöma kvaliteten i förhållande till prislappen på insatserna. Detta kan vara en orsak till att man i intervjuerna i så stor utsträckning talade om kostnader istället för resultat. Ambitioner om effektiviseringar tycks landa i ekonomiseringar, kanske för att kostnader är lättare att mäta. Att kostnadsmedvetandet i den undersökta stadsdelen var centralt en längre tid före marknadsorienteringen, kan också tyda på att implicita ekonomiseringsmotiv bidrog till omorganisationen.

Kanske är det enklast att förklara studiens resultat utifrån det nyinstitutionella organisationsperspektiv som lanserades av bland andra Meyer och Rowan (1991, se även DiMaggio \& Powell 1991). Här ses människobehandlande organisationer främst som legitimitetssträvande och därmed receptiva för omgivningens förväntningar. Det finns ett tryck på offentlig sektor, och därmed även på socialtjänsten, att bland annat med hjälp av marknadsorientering åstadkomma resultat med begränsade ekonomiska medel. Att tillskapa en organisation som på ytan tycks leva upp till dessa krav, trots uppenbara svårigheter att förverkliga sådana mål, torde ge en förbättrad legitimitet hos omgivningen (se även Kirkpatrick et al. 1999). På liknande sätt kan också klyftan mellan de politiska ambitionerna att marknadsorientera barnavården i Stockholm och de begränsade avtrycken i den praktiska verksamheten förklaras.

Denna artikel har varit ett försök att beskriva vad som kan ske i en befintlig barnavårdsorganisation när marknadsorienterade lösningar eftersträvas på en politisk nivå. Studien har genererat ett flertal hypoteser om svårigheter att omsätta idéer om marknadsorientering i praktiken. Det finns skäl att pröva dessa hypoteser i vidare forskning på området. Visserligen är den form av organisering man valt i den undersökta kommundelen ovanlig, men element av den återfinns även i andra typer av marknadsinspirerade barnavårdsorganisationer. Marknadsorienteringens olika former - samt om och hur dessa kan förenas med social barnavård - är en fråga som förtjänar ytterligare empirisk belysning. Detta kan göras med hjälp av fallstudier, men också genom bredare empiriska kartläggningar av fenomenets omfattning och spridning. 


\section{Litteratur}

Bergmark, Åke (1994) "Socialbidragen i den nya socialtjänsten", i Petterson, Ulla (red.) Socialtjänstens klientarbete. Från vision till marknad? Lund: Studentlitteratur.

Blom, Björn (1998) Marknadsorientering av socialtjänstens individ- och familjeomsorg: om villkor, processer och konsekvenser. Umeå: Umeå universitet, institutionen för socialt arbete.

Blomberg, Staffan (2004) Specialiserad biståndshandläggning inom den kommunala äldreomsorgen. Genomförandet av en organisationsreform och dess praktik. Lund: Dissertation.

Bogason, Peter (1998) "Changes in the Scandinavian model. From bureaucratic command to interorganizational negotiation". Public administration, 76:2, 335-354.

Christensen, Tom \& Lagreid, Per (2002) "Introduction", i Tom Cristensen, \& Per Lagreid, (red.) New public management. The transformation of ideas and practise. Hamshire: Ashgate.

DiMaggio, Paul \& Powell, Walter (1991) (red.) New institutionalism in organizational analysis. Chicago: University of Chicago press.

Fernler, Karin (2002) „Generella modeller och lokala lösningar" i Bengt Jacobsson (red.) Organisationsexperiment $i$ kommuner och landsting. Stockholm: Santérus

Harris, John (1998) "Scientific management, bureau-professionalism, new mangerialism: the labour process of state social work". British journal of social work, 28:6, 839-862.

Johansson, Staffan (2002a) Socialtjänsten som organisation. En forskningsöversikt. Socialstyrelsen

Johansson, Roine(2002b) Nyinstitutionalismen inom organisationsanalysen. Lund: Studenlitteratur

Kirkpatrick Ian, Kitchener Martin, Owen Diane, Whipp Richard (1999) „Un-charted territory? Experiences of the purchaser/provider split in local authority children's services" British journal of social work 29:5, 707-72.

Kröger, Teppo (1999) "Local history case study: the unique and the general in the emergence of social care services", i Karvinen Synnöve, Pösö Tarja \& Satka Mirja (red.) Reconstructing social work research. Jyväskylä: SoPhi, University of Jyväskylä.
Lane, Jan-Erik (2000) New public management. London: Routledge

Lundström, Tommy (2000) "Quasi-Märkte ohne Qualitetskontrolle? Kommunalverwaltungen, gemeinnützige Träger und Privatunternehmen in der schwedischen Jugenhilfe« i Privatisierung und Wettbewerb in der Jugendhilfe. Marktorientierte Modernisierungsstrategien in internationaler Perspektive. Neuwied: Luchterhand.

Meyer, John \& Rowen, Brian (1991) »Institutionalised organisations: formal structure as myth and ceremony“ i Paul DiMaggio \& Walter Powell, (red.) New institutionalism in organisational analysis. Chicago: University of Chicago press.

Montin, Stig (1997) »New public management på svenskau. Politica, 29X, 261-278.

Pollit, Christopher \& Bouckaert, Geert (2000) Public management reform: a comparative analysis. Oxford: Oxford university press.

Sahlin-Andersson, Kerstin (2002) «National, international and transnational constructions of new public management « i Tom Cristensen \& Per Laegreid(red.) New public management. The transformation of ideas and practise. Hamshire: Ashgate.

Sallnäs, Marie (2000) Barnavårdens institutioner - framväxt ideologi och struktur. Stockholm: Stockholms universitet, Socialhögskolan.

Stadsledningskontoret (2000) Kartläggning av vilka verksamheter/arbetsprocesser inom individ- och familjeomsorgen som kan konkurrensutsättas. Tjänsteutlåtande till kommunstyrelsen i Stockholms stad.

Stake, Robert (1994) "Case studies" i Denxin, Norman \& Lincoln, Yvonna, (red.) Handbook of qualitative research. London: Sage.

Stenius, Kerstin (1999) Privat och offentligt i svensk alkoholistvård: arbetsfördelning, samverkan och styrning under 1900-talet. Lund: Arkiv

Stockholms stad (2002) Information om social tjänstförvaltningen. www.sot.stockholm.se

Stoecker, Randy (1991) „Evaluating and rethinking the case study". The sociological review, 39:1, 88-112.

Svendsen, Tore (2001) Utvärdering av organisationsförändringar vid Östermalms stadsdelsförvaltning. Stockholm: Stockholms universtiet, 
institutionen för socialt arbete.

Trydegård, Gun-Britt (2001) „Välfärdstjänster till salu» i Szebehely, Marta. (red.) Välfärdstjänster i omvandling. Stockholm: SOU 2002:52.

Yin, Robert (1994) Case study research: design and methods. London: Sage.

USK (2002) Områdesfakta. Utrednings- och statistikkontoret. www.usk.stockholm.se.

Westrup, Ulrika (2002) Gränsöverskridande styr- ning. Om krav på ekonomisk styrning $i$ social verksamhet inriktad mot barn och ungdomar. Lund: Ekonomihögskolan.

Östermalms stadsdelsförvaltning (2000) Organisationsförändring inom programområdet Arbete och Bistånd. Tjänsteutlåtande, Östermalms stadsdelsförvaltning, 2000-05-11

Östermalms stadsdelsförvaltning (2002) Extern öppenvård. Internt budgetdokument.

\section{Summary}

\section{New public management in Swedish child welfare A study of agencies in the city of Stockholm}

This article focuses on organizational elements in child welfare sorting under the concept New Public Management (NPM). The city of Stockholm - where local political ambitions to pursue competition and privatization have been strongly articulated - has been analysed in two approaches. First, the impact of NPM elements in the city's 18 districts has been studied through documents and telephone interviews with personnel in middle management position in child welfare agencies. The overall impression is that political ambitions seem to have had a rather low impact in the districts. Hardly any privatization has occurred and purchases from private service providers have a subordinate position.

Second, based on results from the telephone interviews, an in-depth study has been conducted of an agency with the most articulated organizational elements in line with the concept of NPM. This agency was the only one of Stockholm's 18 agencies that had an organizational purchaser/provider split. The study was conducted through interviews with social workers and person- nel in middle management position as well as by studying written documents. Results indicate that the implementation of NPM elements was introduced after a period of retrenchment and that the new organizational elements were met with great scepticism. The study also shows that even though the work was organized in a purchase/provider split, it was difficult to establish privatization of and competition for the provision of services. A possible explanation is that underlying economic incentives to reduce cost, rather than making the organization more efficient, influenced the cosmetic outcome. This outcome, as well as the low impact of NPM in Stockholm as a whole, is discussed in principle. In particular, difficulties in making human processing organizations more efficient are brought to the fore. The scarcity of evaluations of child welfare services entails difficulties in determining the relation between the price and the quality of these services. The determination of the relation between price and quality is essential in assessing cost-efficient alternatives when purchasing services. 